\title{
Evidence for gene flow differs from observed dispersal patterns in the Humboldt penguin, Spheniscus humboldti
}

\author{
Jacqueline A. Schlosser · Jean M. Dubach - Trenton W. J. Garner · Braulio Araya • \\ Mariano Bernal $\cdot$ Alejandro Simeone $\cdot$ Kimberly A. Smith $\cdot$ Roberta S. Wallace
}

Received: 22 January 2008/Accepted: 8 July 2008/Published online: 8 August 2008

(C) Springer Science+Business Media B.V. 2008

\begin{abstract}
The Humboldt penguin, once common throughout its range, is today listed as Vulnerable by the IUCN. Mark-recapture and telemetry studies indicate that adult Humboldt penguins are sedentary, suggesting strong genetic differentiation between colonies. We developed genotypes for 336 individuals at 12 microsatellite loci sampled at four different localities spanning the entire range of this species. Results show that long-term gene flow has occurred but appears to be affected by geographic distance as pairwise $F_{\mathrm{ST}}$ comparisons involving the colony at Punta San Juan (Peru) and the two colonies at Algarrobo (central Chile) and $\mathrm{Pu}-$ ñihuil (southern Chile) are significant. Bayesian estimates of recent migration rates indicate substantial dispersal among all colonies. Despite the dramatic decline in numbers, we did not observe a bottleneck in any population. Furthermore, we did not detect a founder effect in the recently discovered colony at Puñihuil. As our indirect estimates signal strong gene flow
\end{abstract}

\section{J. A. Schlosser}

Department of Biological Sciences, University of Illinois at

Chicago, 845 W. Taylor Street, Chicago, IL 60607, USA

J. A. Schlosser · J. M. Dubach

Conservation Sciences, Brookfield Zoo, 3300 Golf Road,

Brookfield, IL 60513, USA

\section{J. A. Schlosser ( $\square)$}

Zurich University of Applied Sciences at Waedenswil,

Postfach 335, Gruental, Waedenswil 8820, Switzerland

e-mail: jacqueline.schlosser@zhaw.ch

T. W. J. Garner

Zoologisches Institut, Universität Zürich,

190 Winterthurerstrasse, Zurich 8057, Switzerland

Present Address:

T. W. J. Garner

Institute of Zoology, Zoological Society of London,

Regents Park, London NW1 4RY, UK between populations, we suggest that Humboldt penguin colonies need to be managed as a metapopulation rather than as discrete management units.

Keywords Humboldt penguin - Gene flow - Dispersal . Population structure $\cdot$ Microsatellites

\section{Introduction}

A central issue in wildlife conservation is the relationship between dispersal and gene flow. In order to manage a species effectively in situ it must be known how philopatric a species is, how much individual movement can be expected among populations, and what consequences these movements will have on population genetic structure and evolutionary potential (Crandall et al. 2000; Fraser and

B. Araya $\cdot$ M. Bernal

Facultad de Ciencias del Mar, Universidad de Valparaiso,

Casilla 5080, Renaca, Vina del Mar, Chile

Present Address:

B. Araya

Anakena 2323, Vina del Mar, Chile

A. Simeone

Departamento de Ecología y Biodiversidad, Facultad de Ecología y Recursos Naturales, Universidad Andrés Bello, República 470, Santiago, Chile

K. A. Smith - R. S. Wallace

Milwaukee County Zoo, 10001 W. Blue Mound Road,

Milwaukee, WI 53226, USA 
Bernatchez 2001). Direct methods such as capture-markrecapture (CMR) have been employed to study dispersal, but these methods systematically bias estimates of dispersal downward (Koenig et al. 1996). Further, while direct methods may detect movement, its potential consequences on population genetic, and hence evolutionary, processes cannot be revealed using such approaches. These limitations can be overcome using indirect methods that estimate both recent migration and gene flow from molecular marker data (Koenig et al. 1996; Wilson and Rannala 2003). Indirect methods of estimating dispersal are not affected by many of the factors that limit direct estimates (e.g., restricted study areas and strong sampling limitations) and also allow determination of the influences dispersal may have on either short- or long-term rates of gene flow (Wilson and Rannala 2003). Since the detection of individuals in non-source populations does not necessarily equate with gene flow, comparisons of patterns of recent and long-term gene flow provide combined data that afford a more realistic view of movement that equates with the evolutionary potential of individual populations (Whitlock and McCauley 1999; Wilson and Rannala 2003), which is of greater conservation importance than individual movement patterns (Crandall et al. 2000). Gene flow between populations maintains the overall genetic variability, presumably allowing species to respond to changing selection pressures (Petit et al. 1998), a crucial issue for the long term survival of a species.

The Humboldt penguin (Spheniscus humboldti) is endemic to the coastal areas affected by the Humboldt Current in the South eastern Pacific. The species breeding range extends from Isla Foca $\left(5^{\circ} \mathrm{S}\right)$, Peru, to Puñihuil $\left(42^{\circ} \mathrm{S}\right)$, Chile (Fig. 1). Like most penguin species, Humboldt penguins are restricted to coastal areas, ground nest in colonies and forage in nearby coastal waters. S. humboldti probably numbered in the hundreds of thousands at the end of the nineteenth century (Johnson 1965), but is currently listed as Vulnerable due to population size reductions attributed to exploitation or habitat alteration (Birdlife International 2004). The current population size is estimated to be at 48,000 (Araya and Bernal unpubl.). Direct estimates of Humboldt penguin's dispersal patterns suggest they form distinct breeding populations with little opportunity for among-colony gene flow (e.g., Wallace et al. 1999). Adults show strong colony fidelity: 1,000 penguins banded as adults at Punta San Juan, Peru, were observed breeding only at this location (Araya et al. 2000). Wallace et al. (1999) banded 400 adult penguins at Algarrobo, Chile, but a mere nineteen birds were sighted at other locations, the majority of which were dead penguins recovered at sea mostly within $50 \mathrm{~km}$ of Algarrobo. A single marked bird was recorded by Wallace et al. (1999) at the Cachagua colony, $88 \mathrm{~km}$ north of Algarrobo, but it is unknown if this individual bred at this location or eventually

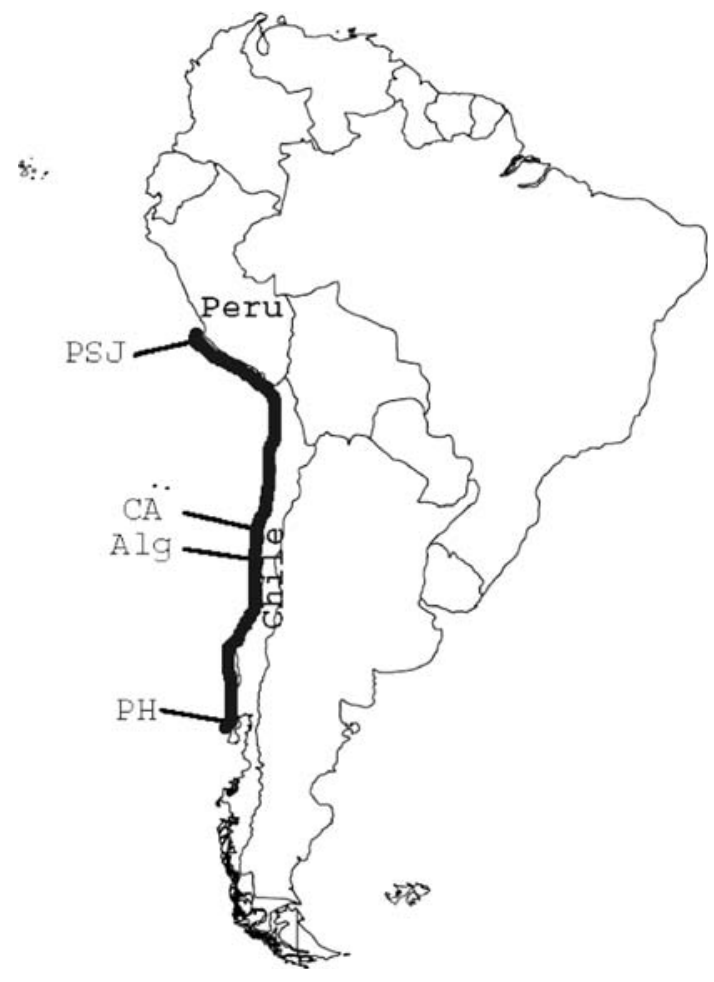

Fig. 1 Map of South America indicating the entire range of the Humboldt penguin and sampling locations (PSJ: Punta San Juan, CA: Cachagua, A: Algarrobo, PH: Puñihuil)

returned to Algarrobo without reproducing at Cachagua. Telemetry and satellite data developed from 12 tagged and breeding Humboldt penguins showed that most foraging during the breeding season occurs within $35 \mathrm{~km}$ of the colony (Culik and Luna-Jorquera 1997a; Culik et al. 1998), while five individuals followed outside of the breeding season foraged within $90 \mathrm{~km}$ of the colony (Culik and LunaJorquera 1997b). Adults also show extreme nest site fidelity. A multiyear study of reproductive behavior determined that approximately $60 \%$ of recaptured adult Humboldt penguins returned to the same nest occupied the previous breeding season. The remaining $40 \%$ either moved to a nest nearby $(\sim 30 \%)$ or moved to a new area within the colony $(\sim 10 \%$, Teare et al. 1998). Polyandrous mating does occur within a breeding colony, but extra-pair copulations do not result in extra-pair fertilization (Schwartz et al. 1999). It is perhaps due to the combination of colony fidelity and nest site fidelity that proposed conservation recommendations to limit penguin bycatch in local fisheries are designed to protect areas immediately adjacent to individual breeding colonies and do not take into account dispersal routes among colonies (Culik and Luna-Jorquera 1997a; Taylor et al. 2002).

These direct data are limited in scope, both geographically and temporally. Useful CMR data for Humboldt penguins is difficult to obtain for several reasons: (1) Their 
breeding range is prohibitively large along the major axis of the species range; (2) many breeding colonies are difficult to access, or completely inaccessible to researchers (i.e., Paredes et al. 2003); (3) reproduction is not predictable and strongly influenced by El Niño events (Araya and Todd 1988; Zavalaga and Paredes 1997; Simeone et al. 2002), and; (4) surveys to date are not standardized (Araya et al. 2000). Furthermore, dispersal of juvenile Humboldt penguins has not been studied until recently (Simeone et al. 2006) and therefore, only very limited data is available. Because it is extremely difficult to overcome these challenges in the field, molecular approaches for estimating dispersal could provide useful information for effective management of Humboldt penguin colonies effectively.

Our research was designed to study dispersal and gene flow indirectly by investigating population structure across four breeding colonies spanning the entire range of this species (Fig. 1). Based on observational data summarized above, we expected to find limited evidence of gene flow and recent dispersal among breeding colonies. Because at least one of our sampling locations is reputed to be a newly founded breeding colony, we sought evidence of recent founding events in all our study locations (Araya and Todd 1988).

\section{Materials and methods}

\section{Sampling locations}

We collected samples from four breeding colonies encompassing the species range of $S$. humboldti (Fig. 1). In Peru, Humboldt penguin colonies have been reported at 22 different locations, but breeding activities, i.e., nesting or nests with chicks, have only been observed at 14 sites (Paredes et al. 2003). Our sample population, Punta San Juan $\left(15^{\circ} 22^{\prime} \mathrm{S}, 75^{\circ} 12^{\prime} \mathrm{W}\right)$, was, and continues to be, the largest breeding area in Peru (Paredes et al. 2003). In the mid-1990s the population was estimated at 1,800 breeding pairs (Zavalaga and Paredes 1997). In Chile, there are at least 14 known breeding sites for the Humboldt penguin (Ellis et al. 1998) of which Cachagua ( $32^{\circ} 35^{\prime} \mathrm{S}, 71^{\circ} 27^{\prime} \mathrm{W}$ ) and Algarrobo $\left(33^{\circ} 21^{\prime} \mathrm{S}, 71^{\circ} 41^{\prime} \mathrm{W}\right)$ were the two major breeding sites in Central Chile at the time of collection (Simeone and Bernal 2000). Puñihuil $\left(41^{\circ} 43^{\prime} \mathrm{S}, 74^{\circ} 02^{\prime} \mathrm{W}\right.$ ) is located at the southernmost tip of the Humboldt penguin's range. There are no published records of any significant breeding colonies between Algarrobo and Puñihuil. Puñihuil is a recently discovered breeding colony which has led some workers to hypothesize that birds displaced during recent El Niño events founded this colony, extending the range of the species over 900 kilometers south (Wilson et al. 1995; Araya and Todd 1988).
Sample collection and DNA extraction

As part of a larger study that also included serological surveys for diseases, Humboldt penguin blood samples were collected during breeding seasons between 1992 and 1997. All sampled birds, with the exception of Cachagua, were permanently marked either by banding a wing and/or inserting a tiny transponder chip under the skin at the rostral portion of the top of the head. This ensured that no individual was sampled for DNA more than once. At Cachagua, samples were collected at the onset of the breeding season as males started to arrive and sampled birds were marked temporarily with water resistant color markers to avoid re-sampling. Blood $(5 \mathrm{ml})$ was collected from the jugular vein using a 22gauge needle and a $5 \mathrm{ml}$ syringe. At Cachagua, blood was obtained from the medial metatarsal vein with 23gauge butterfly blood collection tubing and a $5 \mathrm{ml}$ syringe.

An aliquot of each blood sample was stored in longterm storage buffer $(100 \mu \mathrm{M}$ Trizma, $100 \mathrm{mM}$ EDTA and $2 \%$ SDS, $\mathrm{pH}$ 8.0) for genetic analysis at the Brookfield Zoo Lab. Genomic DNA was extracted from blood following the protocol of Sambrook et al. (1989). Extracted samples were cleaned using three successive washes (equilibrated phenol, phenol/chlorophorm/isoamyl alcohol (25:24:1), and chloroform/isoamyl alcohol (24:1)), followed by precipitation with $3 \mathrm{M}$ sodium acetate and $100 \%$ ethanol.

Microsatellite analyses and validation

Microsatellite primers were developed as described in Schlosser et al. (2003) and Garner et al. (2000). We screened 28 potential microsatellite primer pairs and found 12 loci with a dinucleotide repeat to be polymorphic (Table 1 describes five new loci, for the remaining seven loci see Schlosser et al. 2003). Forward primers were fluorescently labeled with WellRed Beckman Coulter dyes. PCR amplification and genotyping was performed as outlined in Schlosser et al. (2003). We used DNA Analysis System Software, version 4.3.9 (Beckman Coulter, Inc.) to visualize and characterize all genotypes. PCR amplification and genotyping was repeated for samples with unique alleles and at least twice randomly for a few individuals throughout the study and at each capillary change to ensure fragment migration time has not shifted.

A large panel of genotypes was also developed from captive Humboldt penguins that were known first order relatives. We used allelic inheritance patterns and the known pedigrees of these captive family groups to validate genotype scores and to detect null alleles. 
Table 1 Microsatellite primer names, expected fragment sizes based on original sequenced clone, annealing temperatures (T), total number of alleles detected in this study (A), and GenBank accession numbers for five previously unpublished microsatellite loci

\begin{tabular}{|c|c|c|c|c|c|}
\hline Locus name & Primer sequence $5^{\prime}-3^{\prime}$ & Size (bp) & $\mathrm{T}\left({ }^{\circ} \mathrm{C}\right)$ & A & GenBank accession number \\
\hline $\operatorname{Sh} 2 \mathrm{Ca} 31$ & $\begin{array}{l}\text { F:ATCACAGCTCCСССТTTCTC } \\
\text { R:AAGGCAAACAGAGTGGGATG }\end{array}$ & 116 & 64 & 11 & AY435087 \\
\hline $\mathrm{Sh} 2 \mathrm{Ca} 40$ & $\begin{array}{l}\text { F:AGCAGCACGCCCTCCCTC } \\
\text { R:TCTCCAGGAAAGCAGGAATC }\end{array}$ & 90 & 63 & 16 & AY435088 \\
\hline $\mathrm{Sh} 2 \mathrm{Ca} 49$ & $\begin{array}{l}\text { F:GCTTTTCCACCAGCTCTTCC } \\
\text { R:TTCTGTTCAAAGCGTGGTTG }\end{array}$ & 122 & 63 & 9 & AY435089 \\
\hline $\mathrm{Sh} 2 \mathrm{Ca} 55$ & $\begin{array}{l}\text { F:TGAGTCTGAGTGCTCAGTTGG } \\
\text { R:AGGGTCTGAAGGACAGCTACC }\end{array}$ & 115 & 63 & 14 & AY435090 \\
\hline $\mathrm{Sh} 2 \mathrm{Ca} 58$ & $\begin{array}{l}\text { F:TACAGCAATGCAGCGTGTGT } \\
\text { R:ACCTGGTAGAGGGCAGTAGT }\end{array}$ & 106 & 63 & 4 & AY435091 \\
\hline
\end{tabular}

All forward primers were labeled and optimized as described by Schlosser et al. (2003)

Genetic variation within and among colonies

Observed and expected heterozygosities for each microsatellite locus between all pairs of loci were calculated for each year within each population using Genepop v. 3.1d (Raymond and Rousset 1995). We used exact tests to examine each locus for fit with the expectations of HardyWeinberg equilibrium (HWE). For those loci that deviated from HWE expectations, Mann-Whitney $U$-tests were used to test for heterozygote deficiency or excess. Significance was determined using the Markov chain method with all parameters left at default settings (Guo and Thompson 1992). Allelic and genotypic differentiation and $F_{\mathrm{ST}}$ among populations and years within Punta San Juan and Algarrobo was evaluated using Genepop. Allelic richness, number of alleles, genetic disequilibrium and $F_{\text {Is }}$ were calculated using FSTAT 2.9.3.2 (Goudet 2002). We used allelic richness rather than allele frequencies to account for variation in sample sizes among our populations.

We tested for deviations from mutation/drift equilibrium using BOTTLENECK (Cornuet and Luikart 1996). Two models of microsatellite evolution were tested: stepwise mutation model (SMM) (Ohta and Kimura 1973) and twophase model (TPM) (Di Rienzo et al. 1994). As suggested by Piry et al. (1997) the proportion of single-step mutations in TPM was set at $95 \%$. The probability of a bottleneck in each population was assessed with the application of the one tailed Wilcoxon's test for heterozygosity excess as it is the most powerful and robust test offered by this program when using less than 20 loci (Piry et al. 1997).

Gene flow among colonies

We did not detect any significant population structure among years within Punta San Juan and Algarrobo, consequently, all further analyses and among-population comparisons were performed using pooled samples for these two sites.

We investigated gene flow among colonies using three approaches. (1) We tested for isolation by distance along the linear distribution of this species by comparing half matrices of pairwise geographic distances and population genetic distances $\left(F_{\mathrm{ST}} /\left(1-F_{\mathrm{ST}}\right)\right)$ using a one dimensional model Mantel test in Genepop (Rousset 1997) with 1,000 permutations and using a Mantel Nonparametric Test Calculator Shareware V. 2.0 with 10,000 permutations (Liedloff 1999). (2) The number of migrants, $N_{\mathrm{m}}$, was estimated based on private alleles (Slatkin 1985), a method that is less sensitive to reverse mutations common in microsatellites (Allen et al. 1995). (3) To estimate migration rates between populations within the past few generations we used BayesAss 1.2 (Wilson and Rannala 2003). This model uses a Markov chain Monte Carlo technique to estimate the proportion of immigrants into a population. It assumes low levels of migration and sets the maximum allowed proportion of immigration into a population at $\sim 30 \%$ per generation. This method provides a highly accurate estimate of migration rate given sufficient genetic differentiation between populations and a sufficient number of loci (for theoretical aspects see Wilson and Rannala 2003). We estimated recent migration rates using $3 \times 10^{6}$ iterations and a sampling frequency of 2000 .

\section{Results}

Genotypic validation

Patterns of allelic inheritance among captive penguins (163 individuals from 42 family groupings) confirmed that individuals were correctly identified as heterozygotes or homozygotes in parent/offspring analyses and that 
microsatellite alleles were codominantly inherited. The analyses also revealed possible null allele(s) at three loci (Sh1Ca12, Sh2Ca22, and Sh2Ca55) in two sire/offspring combinations. However, for two of these loci, loci $\mathrm{Sh} 2 \mathrm{Ca} 22$ and Sh2Ca55, null alleles were detected in one family for which no DNA from the dam was available for comparison. In this family, the chick and sire were homozygous for different alleles.

A total of 22 individuals from among our wild samples (13 from Algarrobo, two from Puñihuil, and seven from Punta San Juan) were not assigned a genotype at locus Sh2Ca40 because PCR amplification consistently generated multiple peaks within the confirmed allele size range that could not be resolved. As this affected such a small fraction of our samples (Bonin et al. 2004) we included this marker in our study and present the data of all 12 loci unless otherwise stated.

\section{Genetic variation within and among colonies}

In total, 336 individuals from four different colonies were genotyped. The total number of alleles detected at a locus ranged from four (locus Sh2Ca58) to 16 (both Sh1Ca16 and Sh2Ca40), averaging 11.5 over all loci (Table 2). Allelic richness varied little among years within colonies, and among colonies (Table 2). Private and rare alleles (alleles found in no more than two populations) were observed in all populations (frequencies of $\leq 0.034$ for private alleles and $\leq 0.058$ for rare alleles, Appendix 1). Multi-locus tests revealed heterozygote deficiency at Algarrobo and Punta San Juan after Bonferroni correction, but no colony $F_{\text {IS }}$ within years or pooled samples within sites were significant after Bonferroni correction (Table 2). Across all populations, two pairs of loci (Sh1Ca16/

Table 2 Descriptive statistics of microsatellite polymorphisms for four Humboldt penguin colonies

\begin{tabular}{lcrrrrrl}
\hline Sample site & Year & \multicolumn{1}{c}{$N$} & $\mathrm{~A}$ & $\mathrm{R}$ & $H_{\mathrm{O}}$ & $H_{\mathrm{E}}$ & $\underline{F}_{\mathrm{IS}}$ \\
\hline Punta San Juan & 1992 & 11 & 5.7 & 5.7 & 0.74 & 0.71 & -0.041 \\
& 1993 & 49 & 7.6 & 5.9 & 0.72 & 0.75 & 0.031 \\
& 1994 & 26 & 8.1 & 6.3 & 0.73 & 0.77 & 0.053 \\
& Total & 86 & 9.5 & 6.0 & 0.73 & 0.75 & 0.034 \\
Cachagua & 1992 & 21 & 6.6 & 5.5 & 0.72 & 0.72 & 0 \\
Algarrobo & 1994 & 114 & 8.8 & 5.6 & 0.73 & 0.73 & 0 \\
& 1995 & 86 & 9.3 & 5.8 & 0.71 & 0.75 & 0.048 \\
& Total & 200 & 10 & 5.7 & 0.72 & 0.73 & 0.021 \\
Puñihuil & 1997 & 29 & 8.2 & 6.0 & 0.69 & 0.73 & 0.06 \\
\hline
\end{tabular}

Statistics partitioned by year and total, allelic richness based on a minimum sample of 11 individuals. $N=$ Number of samples, $\mathrm{A}=$ average number of alleles, $\mathrm{R}=$ allelic richness, $H_{\mathrm{O}}=$ average observed heterozygosity, $H_{\mathrm{E}}=$ average expected heterozygosity, and $F_{\text {IS }}$
Sh2Ca40 and Sh2Ca22/Sh2Ca55) were in genetic disequilibrium after Bonferroni correction $(P<0.001)$.

Genic and genotypic differentiation over all loci among years within sites was non significant except for allelic differentiation between Punta San Juan 1993 and 1994 $(P<0.05)$. The allelic distribution across all four colonies, with years pooled, was significantly $(P<0.05)$ different at seven of the 12 loci (Sh1Ca9, Sh1Ca12, Sh1Ca17, Sh2, Ca22, Sh2Ca58, Sh2Ca49 and ShCa31). Significant genotypic differentiation was detected after Bonferroni correction $(P<0.0125)$ at six of the 12 loci (Sh1Ca9, Sh1Ca12, Sh1Ca17, Sh2Ca31, Sh2Ca49 and Sh2Ca58). Over all loci, both allelic and genotypic differentiation were highly significant after Bonferroni correction $(P<0.001)$.

Locus Sh2Ca22, and Sh2Ca40 were excluded from all $F_{\text {ST }}$ analyses because they were shown to be in linkage disequilibrium with locus Sh2Ca55 and Sh1Ca16, respectively. Within colonies, pairwise Weir and Cockerham (1984) $F_{\mathrm{ST}}$ values $(\theta)$ were low and not significant $(P>0.05)$ between years, at Algarrobo $F_{\mathrm{ST}}$ was 0.0017 between 1994 and 1995 and at Punta San Juan $F_{\mathrm{ST}}$ ranged from 0.0010 to 0.0086 . When samples were pooled for each colony, $F_{\mathrm{ST}}$ values were also very low, ranging from -0.0010 to +0.0104 and pairwise $F_{\mathrm{ST}}$ were significant $(P<0.05$, Table 3$)$ between Punta San Juan and Algarrobo, Punta San Juan and Puñihuil, and Algarrobo and Puñihuil. All $F_{\mathrm{ST}}$ analyses were also run without locus Sh1Ca12, Sh2Ca22 and Sh2Ca55 to control for effects potentially caused by null alleles that may be operating at these loci. As this did not affect the outcome of the $F_{\text {ST }}$ analyses, we present the results for 10 loci. To determine if differences in sample size were having an effect, the same pairwise differentiation tests were run with a randomly selected sample size of 50 individuals from Algarrobo. These analyses yielded the same results.

No bottleneck or founder effect was detected in any population, including Puñihuil, under both the SMM and TPM. Under the assumptions of these two models all four colonies were in mutation-drift equilibrium.

Table 3 Pairwise geographic distance $(\mathrm{km})$ and $F_{\mathrm{ST}}(\theta)$ values for all possible colony combinations

\begin{tabular}{llllr}
\hline & Punta San Juan & Cachagua & Algarrobo & Puñihuil \\
\hline Punta San Juan & - & 1,952 & 2,031 & 2,932 \\
Cachagua & 0.0083 & - & 88 & 1,041 \\
Algarrobo & $0.0078^{*}$ & -0.0010 & - & 953 \\
Puñihuil & $0.0104^{*}$ & 0.0020 & $0.0020^{*}$ & - \\
\hline
\end{tabular}

Geographic distance is located above the diagonal, and $F_{\mathrm{ST}}$ below. * indicates a significant $F_{\mathrm{ST}}$ value after Bonferroni correction $(P<0.05)$ 
Table 4 Indirect estimates of recent migration rate, $\mathrm{m}$

\begin{tabular}{lllll}
\hline & Punta San Juan & Cachagua & Algarrobo & Puñihuil \\
\hline Punta San Juan & $\mathbf{0 . 7 6}$ & 0.17 & 0.25 & 0.17 \\
& $(0.73,0.80)$ & $(0.10,0.24)$ & $(0.22,0.27)$ & $(0.11,0.23)$ \\
\multirow{2}{*}{ Cachagua } & 0.00 & $\mathbf{0 . 6 8}$ & 0.00 & 0.01 \\
& $(0.00,0.01)$ & $(0.67,0.72)$ & $(0.00,0.01)$ & $(0.00,0.03)$ \\
\multirow{2}{*}{ Algarrobo } & 0.22 & 0.14 & $\mathbf{0 . 7 5}$ & 0.14 \\
& $(0.19,0.26)$ & $(0.07,0.21)$ & $(0.07,0.21)$ & $(0.08,0.21)$ \\
\multirow{2}{*}{ Puñihuil } & 0.01 & 0.01 & 0.00 & $\mathbf{0 . 6 8}$ \\
& $(0.00,0.03)$ & $(0.00,0.05)$ & $(0.00,0.01)$ & $(0.67,0.71)$ \\
\hline
\end{tabular}

Source populations are given in rows, recipient populations in columns

Values in bold along the diagonal are self-recipient rates. Values in parentheses are $95 \%$ confidence intervals. Standard deviations for all distributions were $<0.05$

\section{Gene flow among colonies}

Results from the Mantel test using the Mantel statistic $Z$ (Liedloff 1999) showed a significant association between genetic and geographic distance $(r=0.98, P<0.05)$ and the results from the rank correlation analysis of Rousset (1997) in Genepop are almost significant $(P=0.07)$. These tests suggest that gene flow among populations is affected by distance. The overall number of migrants $\left(N_{\mathrm{m}}\right)$, when calculated using Slatkin's private allele method (1985) and corrected for size, was estimated to be 9 . The greatest amount of migration estimated using this method was between Punta San Juan and Algarrobo with 10 migrants per generation. Estimates of recent migration using the algorithm of Wilson and Rannala (2003) indicated levels of natal philopatry between 68 and $76 \%$ (Table 4). These results also suggest that Punta San Juan serves as a source population, with a migration rate of at least 0.17 into the three populations to the south.

\section{Discussion}

While it is assumed that young marine birds "make active decisions about where to breed" before they reproduce for the first time, many young are philopatric and will return to their natal site for reproduction (Coulson 2002). In most penguin species, adults breed within a few hundred meters of the nest-site where they hatched (Williams 1995) and field observations of Humboldt penguins suggest strong colony fidelity (e.g., Teare et al. 1998). This type of behavior should inevitably lead to significant population genetic differentiation among all breeding locales and strong global population genetic structure.
Population structure

Certainly, our analyses revealed long term structure among colonies, as we detected significant global differences in allelic and genotypic distributions across populations and three significant pairwise $F_{\mathrm{ST}}$ comparisons. The significant pairwise comparisons involved Punta San Juan and the two colonies farthest south of it, Algarrobo and Puñihuil. Cachagua, a major Chilean breeding locale in central Chile, was not significantly different from any colony and also lacked unique alleles. However, the sample size from this location was small and taken at the onset of breeding season, raising the possibility that our patterns of differentiation for this colony may be affected by sampling bias and proximity to the Algarrobo population.

Although the number of Humboldt penguins has decreased dramatically over the past 200 years microsatellite data do not show evidence of a bottleneck. None of the four colonies showed any significant heterozygosity excess under the SMM and TPM and when pooled, the total sample appeared to be in mutation-drift equilibrium. Whitehouse and Harley (2001) advised caution when performing this kind of analysis after they failed to detect population size reduction in post-bottleneck elephant populations. Nevertheless, we detected no difference in allelic richness between colonies and rare and/or unique alleles were detected in all colonies save Cachagua, which would not be the case if recent population declines had affected population genetic variability. Observed and expected heterozygosity was also equally high at all four locations. All these results indicate that while some of the Humboldt penguin colonies have decreased in size and the species is in decline (Zavalaga and Paredes 1997), the current population is still large enough to maintain high genetic diversity.

Cassens et al. (2005) reported similar findings for the Peruvian population of the dusky dolphin (Lagenorhynchus obscurus). This species has also declined in population size along the Peruvian coast due to combined forces of El Niño fluctuations and human factors, but appears to be maintaining high levels of genetic variation. While these two studies indicate that genetic diversity can be maintained during population decline, the long-term effects of these external factors could be substantial and warrant further monitoring.

Finally, the lack of evidence for a bottleneck, the presence of rare alleles and high levels of observed and expected heterozygosity refute the hypothesis that Puñihuil was founded by penguins displaced during a recent El Niño event. Instead, the population at Puñihuil has probably been overlooked in past censuses, as suggested by Araya and Todd (1988). 
Gene flow among colonies

Direct estimates of dispersal through CMR suggest very limited rates and have been primarily made following adult birds. However, Simeone et al. (2006) recently showed that $1.9 \%$ or five of 267 Humboldt penguins marked as chicks at their natal colony in Algarrobo returned to breed to the same colony, while $1.5 \%$ or four of the birds where found nesting elsewhere. Two more birds $(0.8 \%)$ were seen prospecting the natal colony, but no breeding was confirmed. First-year mortality in Spheniscus penguins is rather high, reaching up to $80 \%$ (e.g., Williams 1995; Whittington et al. 2005) possibly explaining the low re-sighting rates. However, indirect estimates of recent migration from this study indicate that movement among colonies is greater than reported by using direct measures of adult dispersal (Araya et al. 2000; Wallace et al. 1999). We estimated an overall migration rate of 9 migrants per generation using Slatkin's method (1985), a frequency that has a strong likelihood of going undetected using current direct methods in Humboldt penguins. Our data from the Mantel tests suggest that dispersal and gene flow are affected by the distance between colonies. The significance level is not high, probably due to the limited number of colonies included in this study.

The level of genetic structure among these four populations of Humboldt penguins is surprising given the level of gene flow among populations indicated by this study. An estimated average of 9 migrants per generation is sufficient to minimize genetic differentiation (Slatkin 1985). In a similar large-scale population genetics study on Adélie penguins, Roeder et al. (2001) expected to find among-colony genetic structure. Population history, current distribution patterns and behavioral and ecological observations of Adélie penguins (Pygoscelis adeliae) all suggested strong population differentiation. Instead, they found no heterogeneity among colonies $\left(F_{\mathrm{ST}}\right.$ values of <0.02), and overall, nine migrants per generation among 13 sampled colonies. Large stable population sizes as well as migration are thought to contribute to the lack of genetic structure among colonies for this species.

Pairwise $F_{\mathrm{ST}}$ estimates among geographically distant populations such as Punta San Juan and Puñihuil are significant, yet our Bayesian analysis suggests that there is asymmetric gene flow into Puñihuil from all populations, including Punta San Juan $(m=0.17)$. However, unsampled ghost populations and small population size at this location could influence these results (Fraser et al. 2007; Johnson et al. 2007; Slatkin 2005). Algarrobo and Punta San Juan are also significantly differentiated at microsatellite loci, yet they have similar migration rates between them of $0.22-0.25$. Very little migration was detected from a large population at Cachagua, possibly due to the limited sample size and timing of sample collection there.

For the Humboldt penguin, migration rates and direction of dispersal might not correlate with annual breeding cycles, but rather are influenced by sharp episodic fluctuations in climate, such as El Niño events and human disturbances that change the relationship between breeding location, habitat quality and demography over the short term for all colony locations. Population counts have shown that numbers of penguins in breeding colonies dropped during El Niño events in 1982/1983 but colony size increased to about $50 \%$ of the original over the next few years (Araya and Todd 1988). More recently, during the 1997-1998 El Niño, Simeone et al. (2002) observed in central Chile a decrease in breeding Humboldt penguins of up to $85 \%$ and an increase by $42-$ $58 \%$ following this event. In Algarrobo, there have been rapid and significant changes in colony sizes. The numbers of breeding individuals were 530 in 1984, 1,000 in 1985, 2000 in 1986, 200 in 1995-1996, and 1,600 in 1996 (Ellis et al. 1998). While a higher mortality rate might contribute to the lower observed density, adults are known to leave the colony to feed farther away and stay out to sea for a longer time span during periods of poor environmental quality, such as El Niño. Dispersal to other colonies during these events that are not affected is possible. Also during those periods of high density, it might be better to disperse rather than attempt to reproduce in an overcrowded environment. Movement out of Algarrobo, in particular, might be explained by direct human habitat modification and a subsequent reduction in the quality of breeding locations or human disturbance. A recent study shows that Humboldt penguins are extremely sensitive to disturbance by humans (Ellenberg et al. 2006). Temporal and spatial fluctuations in habitat quality and high and chaotic population densities are both known to positively influence dispersal propensities (Dieckmann et al. 1999; Johnson and Gaines 1990).

Current research on wide ranging species such as Adélie penguins (Roeder et al. 2001), dusky dolphins (Cassens et al. 2005), gyrfalcons (Johnson et al. 2007) as well as this study, demonstrates the importance of genetic studies for species conservation, where direction and magnitude of migration and population structure that are difficult to observe in the wild can be measured. To designate management units, conservationists need to know whether a species, or part of it, consists of one or more metapopulations or of multiple genetically distinct populations. 


\section{Conservation implication}

The Humboldt penguin is considered as threatened with extinction due to demographic decline (Birdlife International 2004) and is protected in Chile and Peru. Our observed patterns of long term and short term gene flow show that colonies can no longer be viewed as separate entities. The depletion of genetic variability, which limits evolutionary potential, and other forms of inbreeding are unlikely to be current issues for the conservation of this species and the loss of a single colony should not be viewed as a tragedy for the species as long as the overall number of colonies is not decreasing. Incidental catches of penguins in fishing nets are common and in some areas they are the main threat to this species (Simeone et al. 1999; Taylor et al. 2002). To reduce the number of penguins killed in fishing nets Culik and LunaJorquera (1997a) suggested protective zones of $35 \mathrm{~km}$ be established around breeding colonies to assure that penguins can forage safely. After studying the foraging pattern of breeding Humboldt penguins, Taylor et al. (2002) recommended that in areas where penguins forage, commercial fisheries should not use surface nets during the night and during the day they should avoid setting nets at depths of 0 $30 \mathrm{~m}$. While these recommendations might help the survival of colonies in areas where they are implemented it does not guarantee the colony's persistence if dispersal and gene flow are inhibited. Conservation efforts should certainly focus on protecting colonies, especially source populations such as Punta San Juan, but dispersal corridors that allow reinforcement of declining colonies or the establishment of new colonies need to be implemented. Marine reserves that include several breeding and foraging sites that allow immigration and emigration rather than colony buffer zones need to be established to take into account the fact that Humboldt penguins may disperse over thousands of kilometers. Within the boundaries of marine reserves, fishing and other human activities need to be regulated so that they do not interfere with penguin migration routes (Lubchenco et al. 2003). Properly designed, these reserves would not only benefit penguins and other seabirds but also local fishing industries, as conservation measures within marine reserves have been shown to increase fishing yields outside the reserves (Lubchenco et al. 2003; Palumbi 2003).

\footnotetext{
Acknowledgements We thank the Milwaukee County Zoo for allowing us to use the Chilean samples, and W. Karesh for providing the samples from Peru. We would like to thank the Servicio Nacional de Pesca for giving us permission to work with the penguins in Chile, and the Cofradía Náutico del Pacífico for granting access to the island of Algarrobo. We are grateful to David Boulanger for the DNA extractions, J. Rudnick for comments. This research was supported by a UIC Provost's Award for Graduate Research, the AZA Conservation Endowment Fund (CEF 1998), and a grant from the Institute of Museum and Library Services (IC-80183-98). Support for TWJG was provided by H.-U. Reyer.
}

Appendix

Appendix 1 Allele frequencies, number of samples (n), observed $\left(H_{\mathrm{o}}\right)$ and expected heterozygosity $\left(H_{\mathrm{e}}\right)$ for each locus in each population

\begin{tabular}{|c|c|c|c|c|c|}
\hline Locus & Allele & $\begin{array}{l}\text { PSJ } \\
n=86\end{array}$ & $\begin{array}{l}\mathrm{CA} \\
n=21\end{array}$ & $\begin{array}{l}\text { Alg } \\
n=200\end{array}$ & $\begin{array}{l}\text { PH } \\
n=29\end{array}$ \\
\hline \multirow[t]{12}{*}{ Sh1Ca9 } & 123 & 0.000 & 0.000 & 0.000 & 0.034 \\
\hline & 125 & 0.017 & 0.024 & 0.025 & 0.000 \\
\hline & 127 & 0.238 & 0.214 & 0.285 & 0.224 \\
\hline & 129 & 0.006 & 0.000 & 0.000 & 0.000 \\
\hline & 131 & 0.006 & 0.000 & 0.000 & 0.000 \\
\hline & 133 & 0.058 & 0.048 & 0.055 & 0.069 \\
\hline & 135 & 0.488 & 0.667 & 0.560 & 0.621 \\
\hline & 137 & 0.163 & 0.024 & 0.052 & 0.052 \\
\hline & 139 & 0.023 & 0.024 & 0.013 & 0.000 \\
\hline & 141 & 0.000 & 0.000 & 0.010 & 0.000 \\
\hline & $H_{\mathrm{o}}$ & $0.570 *$ & 0.429 & 0.550 & 0.655 \\
\hline & $H_{\mathrm{e}}$ & 0.678 & 0.518 & 0.600 & 0.566 \\
\hline \multirow[t]{17}{*}{ Sh1Ca12 } & 117 & 0.029 & 0.000 & 0.023 & 0.017 \\
\hline & 121 & 0.012 & 0.000 & 0.000 & 0.000 \\
\hline & 123 & 0.058 & 0.048 & 0.038 & 0.034 \\
\hline & 125 & 0.012 & 0.000 & 0.005 & 0.017 \\
\hline & 127 & 0.116 & 0.119 & 0.170 & 0.207 \\
\hline & 129 & 0.145 & 0.262 & 0.243 & 0.207 \\
\hline & 131 & 0.128 & 0.071 & 0.085 & 0.069 \\
\hline & 133 & 0.058 & 0.000 & 0.007 & 0.000 \\
\hline & 135 & 0.174 & 0.167 & 0.125 & 0.190 \\
\hline & 137 & 0.000 & 0.000 & 0.002 & 0.034 \\
\hline & 139 & 0.052 & 0.024 & 0.007 & 0.034 \\
\hline & 141 & 0.174 & 0.286 & 0.240 & 0.121 \\
\hline & 143 & 0.012 & 0.000 & 0.025 & 0.052 \\
\hline & 145 & 0.012 & 0.024 & 0.030 & 0.017 \\
\hline & 147 & 0.017 & 0.000 & 0.000 & 0.000 \\
\hline & $H_{\mathrm{o}}$ & 0.884 & 0.857 & 0.825 & 0.828 \\
\hline & $H_{\mathrm{e}}$ & 0.882 & 0.819 & 0.830 & 0.867 \\
\hline \multirow[t]{14}{*}{ Sh1Ca16 } & 90 & 0.006 & 0.000 & 0.000 & 0.000 \\
\hline & 92 & 0.047 & 0.048 & 0.035 & 0.034 \\
\hline & 96 & 0.000 & 0.000 & 0.005 & 0.000 \\
\hline & 98 & 0.366 & 0.333 & 0.347 & 0.241 \\
\hline & 100 & 0.145 & 0.071 & 0.087 & 0.103 \\
\hline & 102 & 0.151 & 0.238 & 0.168 & 0.224 \\
\hline & 104 & 0.023 & 0.000 & 0.043 & 0.052 \\
\hline & 106 & 0.058 & 0.071 & 0.065 & 0.052 \\
\hline & 108 & 0.087 & 0.119 & 0.115 & 0.138 \\
\hline & 110 & 0.052 & 0.048 & 0.045 & 0.052 \\
\hline & 112 & 0.035 & 0.000 & 0.043 & 0.017 \\
\hline & 114 & 0.017 & 0.071 & 0.035 & 0.017 \\
\hline & 116 & 0.006 & 0.000 & 0.010 & 0.000 \\
\hline & 118 & 0.000 & 0.000 & 0.002 & 0.017 \\
\hline
\end{tabular}


Appendix 1 continued

\begin{tabular}{|c|c|c|c|c|c|}
\hline Locus & Allele & $\begin{array}{l}\text { PSJ } \\
n=86\end{array}$ & $\begin{array}{l}\text { CA } \\
n=21\end{array}$ & $\begin{array}{l}\mathrm{Alg} \\
n=200\end{array}$ & $\begin{array}{l}\text { PH } \\
n=29\end{array}$ \\
\hline \multirow{19}{*}{ Sh1Ca17 } & 120 & 0.006 & 0.000 & 0.000 & 0.017 \\
\hline & 122 & 0.000 & 0.000 & 0.000 & 0.034 \\
\hline & $H_{\mathrm{o}}$ & 0.826 & 0.714 & $0.77 *$ & 0.897 \\
\hline & $H_{\mathrm{e}}$ & 0.809 & 0.818 & 0.866 & 0.820 \\
\hline & 97 & 0.006 & 0.000 & 0.002 & 0.034 \\
\hline & 101 & 0.000 & 0.000 & 0.002 & 0.000 \\
\hline & 10 & 0.000 & 0.000 & 0.000 & 0.034 \\
\hline & 105 & 0.099 & 0.000 & 0.075 & 0.069 \\
\hline & 107 & 0.395 & 0.429 & 0.270 & 0.224 \\
\hline & 109 & 0.081 & 0.214 & 0.225 & 0.121 \\
\hline & 111 & 0.099 & 0.095 & 0.090 & 0.052 \\
\hline & 113 & 0.058 & 0.071 & 0.100 & 0.121 \\
\hline & 115 & 0.058 & 0.095 & 0.075 & 0.155 \\
\hline & 117 & 0.012 & 0.000 & 0.025 & 0.052 \\
\hline & 119 & 0.186 & 0.095 & 0.087 & 0.103 \\
\hline & 121 & 0.006 & 0.000 & 0.045 & 0.034 \\
\hline & 123 & 0.000 & 0.000 & 0.002 & 0.000 \\
\hline & $H_{\mathrm{o}}$ & 0.744 & 0.809 & 0.835 & 0.862 \\
\hline & $H_{\mathrm{e}}$ & 0.780 & 0.756 & 0.839 & 0.887 \\
\hline \multirow[t]{10}{*}{ Sh2Ca12 } & 97 & 0.017 & 0.000 & 0.002 & 0.000 \\
\hline & 99 & 0.203 & 0.262 & 0.203 & 0.241 \\
\hline & 101 & 0.198 & 0.167 & 0.213 & 0.155 \\
\hline & 103 & 0.140 & 0.071 & 0.083 & 0.138 \\
\hline & 107 & 0.407 & 0.452 & 0.435 & 0.466 \\
\hline & 109 & 0.006 & 0.024 & 0.018 & 0.000 \\
\hline & 111 & 0.029 & 0.024 & 0.040 & 0.000 \\
\hline & 113 & 0.000 & 0.000 & 0.007 & 0.000 \\
\hline & $H_{\mathrm{o}}$ & 0.733 & 0.714 & 0.740 & 0.724 \\
\hline & $H_{\mathrm{e}}$ & 0.737 & 0.710 & 0.718 & 0.694 \\
\hline \multirow[t]{11}{*}{$\mathrm{Sh} 2 \mathrm{Ca} 21$} & 114 & 0.169 & 0.214 & 0.220 & 0.241 \\
\hline & 118 & 0.076 & 0.167 & 0.115 & 0.069 \\
\hline & 120 & 0.558 & 0.571 & 0.522 & 0.586 \\
\hline & 122 & 0.006 & 0.000 & 0.002 & 0.017 \\
\hline & 124 & 0.093 & 0.048 & 0.060 & 0.034 \\
\hline & 126 & 0.029 & 0.000 & 0.018 & 0.000 \\
\hline & 128 & 0.023 & 0.000 & 0.015 & 0.000 \\
\hline & 130 & 0.041 & 0.000 & 0.043 & 0.017 \\
\hline & 134 & 0.006 & 0.000 & 0.005 & 0.034 \\
\hline & $H_{\mathrm{o}}$ & 0.581 & 0.524 & 0.670 & 0.517 \\
\hline & $H_{\mathrm{e}}$ & 0.646 & 0.612 & 0.661 & 0.601 \\
\hline Locus & Allele & $n=96$ & $n=21$ & $n=200$ & $n=29$ \\
\hline \multirow[t]{4}{*}{$\mathrm{Sh} 2 \mathrm{Ca} 22$} & 94 & 0.337 & 0.381 & 0.407 & 0.466 \\
\hline & 96 & 0.064 & 0.000 & 0.055 & 0.069 \\
\hline & 100 & 0.000 & 0.000 & 0.002 & 0.000 \\
\hline & 104 & 0.047 & 0.048 & 0.027 & 0.017 \\
\hline
\end{tabular}

Appendix 1 continued

\begin{tabular}{|c|c|c|c|c|c|}
\hline Locus & Allele & $n=96$ & $n=21$ & $n=200$ & $n=29$ \\
\hline & 108 & 0.041 & 0.048 & 0.030 & 0.000 \\
\hline & 112 & 0.000 & 0.000 & 0.005 & 0.000 \\
\hline & 114 & 0.262 & 0.190 & 0.245 & 0.293 \\
\hline & 116 & 0.029 & 0.000 & 0.013 & 0.034 \\
\hline & 118 & 0.169 & 0.262 & 0.183 & 0.103 \\
\hline & 120 & 0.000 & 0.024 & 0.020 & 0.000 \\
\hline & 122 & 0.000 & 0.000 & 0.010 & 0.017 \\
\hline & 124 & 0.023 & 0.024 & 0.002 & 0.000 \\
\hline & 128 & 0.029 & 0.024 & 0.000 & 0.000 \\
\hline & $H_{\mathrm{o}}$ & $0.686^{*}$ & 0.857 & $0.715^{*}$ & $0.414 *$ \\
\hline & $H_{\mathrm{e}}$ & 0.784 & 0.762 & 0.737 & 0.692 \\
\hline Locus & Allele & $n=85$ & $n=21$ & $n=200$ & $n=29$ \\
\hline \multirow[t]{13}{*}{ Sh2Ca31 } & 108 & 0.006 & 0.000 & 0.000 & 0.000 \\
\hline & 114 & 0.000 & 0.000 & 0.002 & 0.034 \\
\hline & 116 & 0.024 & 0.000 & 0.000 & 0.017 \\
\hline & 118 & 0.224 & 0.214 & 0.333 & 0.310 \\
\hline & 120 & 0.118 & 0.024 & 0.035 & 0.034 \\
\hline & 122 & 0.141 & 0.095 & 0.130 & 0.052 \\
\hline & 124 & 0.224 & 0.405 & 0.228 & 0.224 \\
\hline & 126 & 0.047 & 0.048 & 0.020 & 0.034 \\
\hline & 128 & 0.165 & 0.167 & 0.180 & 0.293 \\
\hline & 130 & 0.047 & 0.048 & 0.058 & 0.000 \\
\hline & 132 & 0.006 & 0.000 & 0.015 & 0.000 \\
\hline & $H_{\mathrm{o}}$ & 0.765 & 0.809 & 0.765 & 0.724 \\
\hline & $H_{\mathrm{e}}$ & 0.839 & 0.767 & 0.785 & 0.774 \\
\hline Locus & Allele & $n=79$ & $n=21$ & $n=187$ & $n=27$ \\
\hline \multirow[t]{18}{*}{$\mathrm{Sh} 2 \mathrm{Ca} 40$} & 84 & 0.019 & 0.048 & 0.008 & 0.000 \\
\hline & 86 & 0.025 & 0.048 & 0.027 & 0.037 \\
\hline & 90 & 0.032 & 0.000 & 0.013 & 0.019 \\
\hline & 92 & 0.354 & 0.286 & 0.361 & 0.259 \\
\hline & 94 & 0.158 & 0.071 & 0.088 & 0.093 \\
\hline & 96 & 0.139 & 0.238 & 0.160 & 0.204 \\
\hline & 98 & 0.032 & 0.000 & 0.040 & 0.056 \\
\hline & 100 & 0.044 & 0.071 & 0.067 & 0.056 \\
\hline & 102 & 0.108 & 0.119 & 0.107 & 0.111 \\
\hline & 104 & 0.044 & 0.048 & 0.045 & 0.074 \\
\hline & 106 & 0.019 & 0.000 & 0.043 & 0.019 \\
\hline & 108 & 0.013 & 0.071 & 0.032 & 0.019 \\
\hline & 110 & 0.006 & 0.000 & 0.005 & 0.000 \\
\hline & 112 & 0.000 & 0.000 & 0.003 & 0.019 \\
\hline & 114 & 0.006 & 0.000 & 0.000 & 0.019 \\
\hline & 116 & 0.000 & 0.000 & 0.000 & 0.019 \\
\hline & $H_{\mathrm{o}}$ & 0.861 & 0.714 & $0.759 *$ & 0.926 \\
\hline & $H_{\mathrm{e}}$ & 0.816 & 0.845 & 0.815 & 0.871 \\
\hline
\end{tabular}


Appendix 1 continued

\begin{tabular}{llllll}
\hline Locus & Allele & $n=86$ & $n=21$ & $n=200$ & $n=29$ \\
\hline Sh2Ca49 & 100 & 0.006 & 0.000 & 0.000 & 0.000 \\
& 108 & 0.000 & 0.000 & 0.005 & 0.000 \\
& 110 & 0.250 & 0.143 & 0.210 & 0.276 \\
& 114 & 0.105 & 0.095 & 0.105 & 0.017 \\
& 116 & 0.163 & 0.405 & 0.310 & 0.397 \\
& 118 & 0.058 & 0.071 & 0.035 & 0.069 \\
& 120 & 0.209 & 0.095 & 0.172 & 0.086 \\
& 122 & 0.110 & 0.119 & 0.065 & 0.052 \\
& 124 & 0.099 & 0.071 & 0.097 & 0.103 \\
& $H_{\mathrm{o}}$ & 0.895 & 0.857 & 0.815 & 0.724 \\
& $H_{\mathrm{e}}$ & 0.836 & 0.792 & 0.806 & 0.754 \\
\hline Sh2Ca55 & Allele & $n=85$ & $n=21$ & $n=200$ & $n=29$ \\
& 94 & 0.000 & 0.000 & 0.005 & 0.000 \\
& 96 & 0.406 & 0.381 & 0.450 & 0.534 \\
& 102 & 0.000 & 0.000 & 0.002 & 0.000 \\
& $H_{\mathrm{e}}$ & 0.491 & 0.507 & 0.506 & 0.589
\end{tabular}

* indicates heterozygote deficiency after Bonferroni correction $(P<0.0042)$

\section{References}

Allen PJ, Amos W, Pomeroy PP, Twiss SD (1995) Microsatellite variation in grey seals (Halichoerus grypus) shows evidence of genetic differentiation between two British breeding colonies. Mol Ecol 4:653-662. doi:10.1111/j.1365-294X.1995.tb00266.x

Araya BM, Todd FS (1988) Status of the Humboldt penguin in Chile following the 1982-1983 El Nino. SPN, September 8-10

Araya B, Garland D, Espinoza G, Sanhuesa A, Simeone AR, Teare A et al (2000) Population and habitat viability assessment for the
Humboldt penguin (Spheniscus humboldti), Final Report. IUCN/ SSC Conservation Breeding Specialist Group, Apple Valley, $\mathrm{MN}$

BirdLife International (2004) Threatened Birds of the World 2004. CD-ROM, BirdLife International, Cambridge, UK

Bonin A, Bellemain E, Bronken Eidesen P, Popanon F, Brochmann C, Taberlet $\mathrm{P}$ (2004) How to track and deal with genotyping errors in populations genetics studies. Mol Ecol 13:3261-3273. doi: 10.1111/j.1365-294X.2004.02346.X

Cassens I, van Waerebeek K, Best P, Tzika A, van Helden A, Crespos E et al (2005) Evidence for male dispersal along the coasts but no migration in pelagic waters in dusky dolphins (Lagenorhynchus obscurus). Mol Ecol 14:107-121. doi:10.1111/j.1365-294X.2004. 02407.x

Cornuet JM, Luikart G (1996) Description and power analysis of two tests for detecting recent population bottlenecks from allele frequency data. Genetics 144:2001-2014

Coulson JC (2002) Colonial breeding in Seabirds. In: Schreiber EA, Burger J (eds) Biology of marine birds. CRC Press, FL, pp $87-113$

Crandall KA, Bininda-Emonds ORP, Mace GM, Wayne RK (2000) Considering evolutionary processes in conservation biology. Trends Ecol Evol 15:290-295. doi:10.1016/S0169-5347(00) 01876-0

Culik BM, Luna-Jorquera G (1997a) Satellite tracking of Humboldt penguins (Spheniscus humboldti) in northern Chile. Mar Biol (Berl) 128:547-556. doi:10.1007/s002270050120

Culik BM, Luna-Jorquera G (1997b) The Humboldt penguin Spheniscus humboldti: a migratory bird? J Ornithol 138:325-330. doi: 10.1007/BF01651558

Culik BM, Luna-Jorquera G, Oyarzo H, Correa H (1998) Humboldt penguins monitored via VHF telemetry. Mar Ecol Prog Ser 162:279-286. doi:10.3354/meps162279

Dieckmann U, O'Hara B, Weisser W (1999) The evolutionary causes of dispersal. Trends Ecol Evol 14:88-90. doi:10.1016/S01695347(98)01571-7

Di Rienzo A, Peterson AC, Garza JC, Valdes AM, Slatkin M, Freimer NB (1994) Mutational processes of simple sequence repeat loci in human populations. Proc Natl Acad Sci USA 91:3166-3170. doi:10.1073/pnas.91.8.3166

Ellenberg U, Mattern T, Seddon PJ, Luna Jorquera G (2006) Physiological and reproductive consequences of human disturbance in Humboldt penguins: the need for species-specific visitor management. Biol Conserv 133:95-106. doi:10.1016/j.biocon. 2006.05.019

Ellis S, Croxall JP, Cooper J (1998) Penguin conservation assessment and managements plan. IUCN/SSC Conservation breeding Specialist Group, Apple Valley, MN, USA

Fraser DJ, Bernatchez L (2001) Adaptive evolutionary conservation: towards a unified concept for defining conservation units. Mol Ecol 10:2741-2752

Fraser DJ, Hansen MM, Østergaard S, Tessier N, Legault M, Bernatchez L (2007) Comparative estimation of effective population sizes and temporal gene flow in two contrasting population systems. Mol Ecol 16:3866-3889. doi:10.1111/j.1365-294X. 2007.03453.x

Garner TWJ, Gautschi B, Röthlisberger S, Reyer H-U (2000) A set of CA repeat microsatellite markers derived from the pool frog, Rana lessonae. Mol Ecol 9:2173-2174. doi:10.1046/j.1365294X.2000.105311.x

Goudet J (2002) FSTAT, version 2.9.3.2. Institute of Ecology, Lausanne, Switzerland. http://www2.unil.ch/popgen/softwares/ fstat.html. Accessed 20 Sep 2007

Guo SW, Thompson EA (1992) Performing the exact test of HardyWeinberg proportion for multiple alleles. Biometrics 48:361372. doi: $10.2307 / 2532296$ 
Johnson AW (1965) The birds of Chile and adjacent regions of Argentina, Bolivia and Peru, vol 1. Platt Establecimientos Gråficos S.A., Buenos Aires

Johnson ML, Gaines MS (1990) Evolution of dispersal: theoretical models and empirical tests using birds and mammals. Annu Rev Ecol Syst 21:449-480. doi:10.1146/annurev.es.21.110190.002313

Johnson JA, Burnham KK, Burnham WA, Mindell DP (2007) Genetic structure among continental and island populations of gyrfalcons. Mol Ecol 16:3145-3160. doi:10.1111/j.1365-294X.2007.03373.x

Koenig WD, Van Vuren D, Hooge PN (1996) Detectability, philopatry, and the distribution of dispersal distances in vertebrates. Trends Ecol Evol 11:514-517. doi:10.1016/S0169-5347 (96)20074-6

Liedloff A (1999) Mantel v2.0: Mantel nonparametric test calculator. Queensland University of Technology, Brisbane

Lubchenco J, Palumbi SR, Geines SD, Andelman S (2003) Plugging a hole in the ocean: the emerging science of marine reserves. Ecol Appl Suppl 13:S3-S7. doi:10.1890/1051-0761(2003)013[0003: PAHITO]2.0.CO;2

Ohta T, Kimura M (1973) A model of mutation appropriate to estimate the number of electrophoretically detectable alleles in a finite population. Genet Res Camb 22:201-204

Palumbi SR (2003) Population genetics, demographic connectivity, and the design of marine reserves. Ecol Appl Suppl 13:S146-S158. doi:10.1890/1051-0761(2003)013[0146:PGDCAT]2.0.CO;2

Paredes R, Zavalaga CB, Battistini G, Majluf P, McGill P (2003) Status of the Humboldt penguin in Peru, 1999-2000. Waterbirds 26:129138. doi:10.1675/1524-4695(2003)026[0129:SOTHPI]2.0.CO;2

Petit RJ, El Mousadik A, Pons O (1998) Identifying populations for conservation on the basis of genetic markers. Conserv Biol 12:844-855. doi:10.1046/j.1523-1739.1998.96489.x

Piry S, Luikart G, Cornuet J-M (1997) BOTTLENECK: a computer program for detecting recent reductions in the effective population size using allele frequency data. J Hered 90:502-503. doi: 10.1093/jhered/90.4.502

Raymond M, Rousset F (1995) GENEPOP (version 1.2): population genetics software for exact tests and ecumenicism. J Hered 86:248-249

Roeder AD, Marshall RK, Mitchelson AJ, Visagathilagar T, Ritchie PA, Love DR et al (2001) Gene flow on the ice: genetic differentiation among Adélie penguin colonies around Antarctica. Mol Ecol 10:1645-1656. doi:10.1046/j.0962-1083.2001.01312.x

Rousset F (1997) Genetic differentiation and estimation of gene flow from F-statistics under isolation by distance. Genetics 145: $1219-1228$

Sambrook J, Fritsch E, Maniatis T (1989) Molecular cloning: a laboratory manual, 2nd edn. Cold Spring Harbor Laboratory Press, New York

Schlosser JA, Garner TWJ, Dubach JM, McElligott AG (2003) Characterization of microsatellite loci in Humboldt penguin (Spheniscus humboldti) and cross-amplification in other penguin species. Mol Ecol Notes 3:62-64. doi:10.1046/j.1471-8286.2003. 00349. $\mathrm{x}$

Schwartz MK, Boness DJ, Schaeff CM, Mailuf P, Perry EA, Fleischer RC (1999) Female-solicited extrapair matings in Humboldt penguins fail to produce extrapair fertilizations. Behav Ecol 10:242-250. doi:10.1093/beheco/10.3.242

Simeone A, Bernal M (2000) Effects of habitat modification on breeding seabirds: a case study in Central Chile. Waterbirds 23:449-456. doi:10.2307/1522182

Simeone A, Bernal M, Meza J (1999) Incidental mortality of Humboldt penguins Spheniscus humboldti in gill nets, central Chile. Mar Ornithol 27:157-161

Simeone A, Araya B, Bernal M, Diebold EN, Grzybowski K, Michaels $\mathrm{M}$ et al (2002) Oceanographic and climatic factors influencing breeding and colony attendance patterns of Humboldt Penguins, Spheniscus humboldti, in central Chile. Mar Ecol Prog Ser 227:43-50. doi:10.3354/meps 227043

Simeone A, Wallace R, Whittington P (2006) Dispersal and philopatry in Humboldt penguins at a breeding colony off central Chile Abstracts XXIV International Ornithological Congress. J Ornithol 147:98

Slatkin M (1985) Rare alleles as indicators of gene flow. Evolution 39:53-65. doi: $10.2307 / 2408516$

Slatkin M (2005) Seeing ghosts: the effect of unsampled populations on migration rates estimated for sampled populations. Mol Ecol 14:67-73. doi:10.1111/j.1365-294X.2004.02393.x

Taylor SS, Marty LL, Boness DJ, Majluf P (2002) Foraging by Humboldt penguins (Spheniscus humboldti) during the chickrearing period: general patterns, sex differences, and recommendations to reduce incidental catches in fishing nets. Can $\mathbf{J}$ Zool 80:700-707. doi:10.1139/z02-046

Teare JA, Diebold EN, Grzybowski K, Michaels MG, Wallace RS, Willis J (1998) Nest-site fidelity in Humboldt penguins (Spheniscus humboldti) at Algarrobo, Chile. Penguin Conserv 11:22-23

Wallace RS, Grzybowski K, Diebold E, Michaels MG, Teare JA, Willis MJ (1999) Movements of Humboldt Penguins from a breeding colony in Chile. Waterbirds 22:441-444. doi:10.2307/1522121

Weir BB, Cockerham CC (1984) Estimating F-statistics for the analysis of population structure. Evolution 38:1358-1370. doi: $10.2307 / 2408641$

Whitehouse AM, Harley EH (2001) Post-bottleneck genetic diversity of elephant populations in South Africa, revealed using microsatellite analysis. Mol Ecol 10:2139-2149. doi:10.1046/j.09621083.2001.01356.x

Whitlock MC, McCauley DE (1999) Indirect measures of gene flow and migration: $F_{\mathrm{ST}}$ does not equal $1 /\left(1+4 N_{\mathrm{m}}\right)$. Heredity 82:117-126. doi:10.1038/sj.hdy.6884960

Whittington P, Klages N, Crawford R, Wolfaardt A, Kemper J (2005) Age at first breeding in the African penguin. Ostrich 76:14-20

Williams TD (1995) Bird families of the world. The penguins. Oxford University Press, New York

Wilson GA, Rannala B (2003) Bayesian inference of recent migration rates using multilocus genotypes. Genetics 163:1177-1191

Wilson RP, Duffy DC, Wilson M-PT, Araya B (1995) Aspects of the ecology of species replacement in Humboldt and Magellanic penguins in Chile. Gerfaut 85:49-61

Zavalaga CB, Paredes R (1997) Humboldt penguins at Punta San Juan, Peru. Penguin Conserv 10:6-8 